\title{
Metabolism of Thiophene-2-carboxylate by a Photosynthetic Bacterium
}

\author{
Hideoki Tanaka, Hidekatsu Maeda, Hideo Suzuki, \\ Akira Kamibayashi and Kenzo TonOMURA* \\ Fermentation Research Institute, Agency of Industrial Science and Technology, \\ Tsukuba, Ibaraki 305, Japan \\ * Department of Agricultural Chemistry, College of Agriculture, \\ University of Osaka Prefecture, Sakai, Osaka 591, Japan
}

Received March 2, 1981

\begin{abstract}
A photosynthetic bacterium, which can grow photosynthetically on benzoate, was isolated from sewage mud. Various kinds of aromatic compounds including heterocyclic aromatic compounds were photometabolized by the washed cells grown photosynthetically on benzoate with no lag period. Among these, thiophene-2-carboxylate was metabolized most rapidly to its $(+)$ tetrahydro derivative. The same strain could also grow on succinate under photosynthetic conditions. However, thiophene-2-carboxylate was only photometabolized after a long lag period by the washed cells grown photosynthetically on succinate, and the metabolite was not its $(+)$ tetrahydro derivative but (+)-3-hydroxytetrahydrothiophene-2-carboxylate. In the presence of chloramphenicol, an inhibitor of protein synthesis, the photometabolism of thiophene-2carboxylate by the washed cells grown photosynthetically on benzoate was not affected at all, but the photometabolism of the same substrate by the washed cells grown photosynthetically on succinate was completely inhibited. These results indicate that a reduction system of broad substrate specificity for aromatic rings is already present in the benzoate-grown cells but absent in the succinate-grown cells. It seems that such a reduction system for aromatic rings is induced by an aromatic substrate.
\end{abstract}

The aerobic degradation of aromatic compounds by microorganisms has been extensively studied, and a variety of pathways have been described. ${ }^{1,2)}$ On the contrary, microbial cleavage of aromatic rings under anaerobic conditions has received less attention. Recently a new pathway has been demonstrated for the anaerobic metabolism of benzoate by microorganisms, whereas it appears that the microbial degradation of heterocyclic aromatic compounds belonging to this category is still rare.

Benzoate is degraded by microorganisms under different anaerobic conditions, such as photometabolism, $^{3,4)}$ nitrate respiration ${ }^{5,6)}$ and methane fermentation. ${ }^{7,8)}$ Recently it has been revealed that the degradation of benzoate under these conditions is initiated by the reduction of a benzene ring and is quite different from that under aerobic conditions. ${ }^{9)}$

We therefore began a study on the anaerobic degradation of heterocyclic aromatic compounds using a photosynthetic bacterium. Thiophene-2-carboxylate, one of the heterocyclic aromatic compounds, was photometabolized more rapidly than any of the other aromatic substrates metabolized. $\alpha$-Picolinate and furan-2-carboxylate were also photometabolized. This report describes the photometabolism of thiophene-2-carboxylate by a photosynthetic bacterium.

\section{MATERIALS AND METHODS}

Media. The basal medium used had the following composition ( $\mathrm{g} /$ liter distilled water): $\mathrm{KH}_{2} \mathrm{PO}_{4}, 0.5 ; \mathrm{NH}_{4} \mathrm{Cl}$, $1.0 ; \mathrm{MgSO}_{4} \cdot 7 \mathrm{H}_{2} \mathrm{O}, 0.5$; yeast extract (Oriental Yeast Industry Ltd., Tokyo), 0.1 ; trace metals solution, $10 \mathrm{ml}$. The trace metals solution contained the following components $\left(\mathrm{mg} /\right.$ liter distilled water): EDTA, 500; $\mathrm{FeSO}_{4}$. $7 \mathrm{H}_{2} \mathrm{O}, 200 ; \mathrm{ZnSO}_{4} \cdot 7 \mathrm{H}_{2} \mathrm{O}, 10 ; \mathrm{MnCl}_{2} \cdot 4 \mathrm{H}_{2} \mathrm{O}, 3 ; \mathrm{H}_{3} \mathrm{BO}_{3}$, $30 ; \mathrm{CoCl}_{2} \cdot 6 \mathrm{H}_{2} \mathrm{O}, 20 ; \mathrm{CuCl}_{2} \cdot 2 \mathrm{H}_{2} \mathrm{O}, 1 ; \mathrm{Ni}\left(\mathrm{NO}_{3}\right)_{2} \cdot 6 \mathrm{H}_{2} \mathrm{O}, 2$; 
$\mathrm{Na}_{2} \mathrm{MoO}_{4} \cdot 2 \mathrm{H}_{2} \mathrm{O}, 3 ; \mathrm{CaCl}_{2} \cdot 2 \mathrm{H}_{2} \mathrm{O}, 100$. The media used for the enrichment cultuer, plate culture, and utilization test of aromatic compounds were prepared by adding benzoic acid $(0.5 \mathrm{~g} /$ liter $)$, succinic acid $(0.5 \mathrm{~g} /$ liter $)$ and Bact agar (Eiken Chemical Ltd., Tokyo) (15 g/liter), and an appropriate aromatic substrate to the above basal medium, respectively. For the preparation of washed cells, a medium containing $1.0 \mathrm{~g} /$ liter of benzoic or succinic acid was used. All of these media were adjusted to $\mathrm{pH} 7.0$ and sterilized by autoclaving $\left(15 \mathrm{~min}\right.$ at $\left.120^{\circ} \mathrm{C}\right)$.

Microorganism. Strain H45-2, a photosynthetic bacterium which can grow photosynthetically on benzoate and is similar to Rhodopseudomonas palustris, was isolated from sewage mud by an enrichment technique with the basal medium containing benzoate as the sole source of carbon. About one gram samples of mud collected locally were placed in $16 \mathrm{ml}$ screw-capped tubes filled with the benzoate-basal medium, and the inoculated media were incubated for 10 to 20 days at $30^{\circ} \mathrm{C}$ in the light. The cultures which showed growth were subcultured several times and then streaked onto plates of the solidified succinate-basal medium. These plate cultures were incubated for several days aerobically in the dark at $30^{\circ} \mathrm{C}$. An organism was isolated on an agar plate and purified by repeating the subculture. The isolated strain was maintained by a monthly subculture in the light in a benzoatebasal medium in a screw-capped tube.

\section{Utilization of aromatic compounds for growth.}

[Photoassimilation]: Utilization of aromatic compounds for growth under photosynthetic conditions was tested by the following procedure. A few drops of the culture liquid prepared by growing strain H45-2 on benzoate under photosynthetic conditions were inoculated into the basal medium containing an aromatic compound, the medium being in $16 \mathrm{ml}$ screw-capped tubes, and the inoculated media were incubated for $1 \sim 3$ weeks at $30^{\circ} \mathrm{C}$ in the light.

[Aerobic assimilation]: The aerobic assimilation test of aromatic compounds was carried out as follows. A few drops of the culture liquid of strain $\mathrm{H} 45-2$ were inoculated into $15 \mathrm{ml}$ of the same medium as that used for the utilization test under photosynthetic conditions in $100 \mathrm{ml}$ cotton-plugged Erlenmeyer flasks. In this case, however, the flasks were incubated on a rotary shaker for several days at $30^{\circ} \mathrm{C}$ in the dark.

Under both photosynthetic and aerobic conditions, growth was assessed by the turbidity at $660 \mathrm{~nm}$. A control experiment was carried out using the basal medium with no aromatic compound.

Photometabolism of aromatic compounds by the washed cells.

[Preparation of the washed cells]: The preculture was carried out as follows. A few drops of the preservative culture liquid of strain $\mathrm{H} 45-2$ were inoculated into the basal medium containing $1.0 \mathrm{~g} /$ liter of benzoate, the medium being in a $60 \mathrm{ml}$ screw-capped tube, and the inoculated medium was incubated for about 10 days at $30^{\circ} \mathrm{C}$ anaerobically in the light. Then this preculture liquid was inoculated into 1 liter of the same medium as that used in the preculture in a 1 liter Roux bottle. The bottle was fitted with a rubber stopper having gas inlet and outlet tubes, and a sampling tube. The bottle was made anaerobic by bubbling cotton-filtered nitrogen gas into the medium, illuminated from the front side with three $20 \mathrm{~W}$ fluorescent lamps, and cultivated at $30^{\circ} \mathrm{C}$. Towards the end of the exponential growth phase when benzoate in the medium had been almost totally consumed (about 6 days), the cells were harvested by centrifugation, washed twice with an equal volume of $0.05 \mathrm{~m}$ phosphate buffer, $\mathrm{pH} 7.0$, and used immediately. The cells grown photosynthetically on succinate as a substrate were prepared by the same procedure as in the case of using benzoate as a substrate, by using the basal medium containing $1.0 \mathrm{~g} /$ liter of succinate. The preculture was carried out by inoculating a few drops of the preservative culture liquid of strain $\mathrm{H} 45-2$ into the succinate-basal medium in a $60 \mathrm{ml}$ screw-capped tube. In this case, the culture neared the end of the exponential growth phase after $3 \sim 4$ days.

[Photometabolism of aromatic compounds by the washed cells ]: A suspension of about $280 \mathrm{mg}$ (dry weight) of the washed cells in $180 \mathrm{ml}$ of $0.05 \mathrm{M}$ phosphate buffer, $\mathrm{pH} 7.0$, was put into a $500 \mathrm{ml}$ Roux bottle fitted with a rubber stopper having gas inlet and outlet tubes and a sampling tube as mentioned above. Nitrogen gas was bubbled into the cell suspension for 20 min under illumination with two $20 \mathrm{~W}$ fluorescent lamps before adding a substrate. Then the photometabolism was started by adding $10 \mathrm{mg}$ of a substrate dissolved in $20 \mathrm{ml}$ of $0.05 \mathrm{M}$ phosphate buffer, $\mathrm{pH}$ 7.0 , to the cell suspension. Photometabolism was allowed to proceed at $30^{\circ} \mathrm{C}$ in the light and nitrogen gas was bubbled through during the whole period. Three $\mathrm{ml}$ aliquots of the suspension were withdrawn periodically, centrifuged, and the UV spectra of the supernatants were measured to follow the disappearance of the substrate. The initial rate of the metabolism was estimated from the slope obtained by plotting the absorbance of the substrate at its $\lambda_{\max }$ against reaction time.

Chemical analyses. The metabolites from thiophene-2carboxylate were analyzed as follows. Sixty $\mathrm{mg}$ and $300 \mathrm{mg}$ of the substrate in 1 liter of $0.05 \mathrm{M}$ phosphate buffer, $\mathrm{pH}$ 7.0, were photometabolized with the cells grown photosynthetically on succinate and benzoate, respectively. In both cases, about $1.3 \mathrm{~g}$ (dry weight) of the washed cells were used.

[Extraction of the metabolites]: After thiophene-2carboxylate was photometabolized with the cells grown on benzoate and succinate for $3 \sim 4$ days and $5 \sim 6$ days, respectively, and the substrate had disappeared completely, the suspension was centrifuged and the resulting supernatant was concentrated to one-tenth of the original 
volume under reduced pressure at $30^{\circ} \mathrm{C}$, acidified to $\mathrm{pH}$ 1.5 with $6 \mathrm{M} \mathrm{HCl}$ after being saturated with sodium chloride, and extracted three times with an equal volume of ethyl acetate. The combined extracts were washed once with a small amount of water, dried with anhydrous sodium sulfate, and the solvent removed in vacuo. The crude extract was obtained as a dark-red viscous oil.

[Gas-liquid chromatography (GLC)]: The methylated samples were prepared by reacting about one $\mathrm{mg}$ of the crude extract with diazomethane by the conventional method and analyzed by GLC using a Hitachi 063 gas chromatograph equipped with a flame ionization detector. Samples were injected onto a stainless steel column $(\phi 3 \mathrm{~mm} \times 1.0 \mathrm{~m})$ packed with $2 \%$ silicone $\mathrm{OV}-1$ on Chromosorb W AW-DMCS, 80 100 mesh, with a $\mathrm{He}$ carrier gas flow rate of $30 \mathrm{ml} / \mathrm{min}$. The temperatures of the injector and detector ports were 180 and $160^{\circ} \mathrm{C}$, respectively. The column temperature was raised from 130 to $160^{\circ} \mathrm{C}$ at a rate of $5^{\circ} \mathrm{C} / \mathrm{min}$.

[Gas-liquid chromatography-Mass spectrometry (GLC$M S$ ) ]: A part of the methylated samples, identical to those used in the GLC analysis, was also analyzed by GLC-MS using a JEOL JMS-D300 GC/MS spectrometer. Samples were injected onto a glass column $(\phi 3 \mathrm{~mm} \times 1.0 \mathrm{~m})$ filled with the same packing as that used in GLC analysis, with a $\mathrm{He}$ carrier gas pressure of $0.8 \mathrm{~kg} / \mathrm{cm}^{2}$. The temperatures of the injector and ion source ports were 160 and $200^{\circ} \mathrm{C}$, respectively. The column temperature was raised from 80 to $160^{\circ} \mathrm{C}$ at a rate of $10^{\circ} \mathrm{C} / \mathrm{min}$. The ionization voltage was $70 \mathrm{eV}$ and the ionization current was $300 \mu \mathrm{A}$.

[Purification and characterization of the metabolites]: The remaining crude extract was applied to a column $(\phi 25 \mathrm{~mm} \times 15 \mathrm{~cm})$ of silica gel and eluted with benzeneethyl acetate. A portion of each fractionated sample was converted to its trimethylsilyl derivative with $\mathrm{N}, \mathrm{O}$ bis(trimethylsilyl)acetamide and each of the trimethylsilylated samples was analyzed by GLC using a Hitachi 063 gas chromatograph equipped with a flame ionization detector. The conditions used were the same as in the case of the analysis of the methylated samples as described above. The fractions containing the main metabolite were combined. The solvents were evaporated in vacuo and the residue was recrystallized from $n$-hexane in the case of the metabolite with the benzoate-grown cells, and from $n$ hexane-ether in the case of the metabolite with the succinate-grown cells, respectively. The purified metabolites thus obtained were analyzed spectrophotometrically with a Hitachi high resolution NMR spectrometer R24-B, a JASCO IRA-1 diffraction grating infrared spectrophotometer and a Hitachi 124 spectrophotometer. The optical rotations were determined with a Union Giken PM-101 automatic digital polarimeter. The melting points were determined on a hot stage with a Yanaco micro melting point apparatus and were uncorrected.

Chemicals. Thiophene-2-carboxylic acid (extra pure grade, colorless fine needles, mp $130.0 \sim 130.5^{\circ} \mathrm{C}$ : lit. $^{10)}$
$129 \sim 130^{\circ} \mathrm{C}$ ) from Wako Pure Chemical Industries, Ltd. (Osaka) was used without further purification. Succinic acid, benzoic acid and the other aromatic compounds except phenylacetic acid were of extra pure or pure grade from Wako Pure Chemical Industries, Ltd. (Osaka). Phenylacetic acid was synthesized by acid hydrolysis of benzyl cyanide prepared from benzyl chloride and potassium cyanide according to the procedure of Adams and Thal. ${ }^{11)}$ Chloramphenicol was obtained from Boeringer Mannheim GmbH (W. Germany). N,O-Bis(trimethylsilyl)acetamide came from Gaskuro Kogyo Co., Ltd. (Tokyo). The silica gel used for column chromatography was Wakogel C-200 from Wako Pure Chemical Industries, Ltd.

\section{RESULTS}

\section{Utilization of aromatic compounds for growth}

Under photosynthetic conditions, strain H45-2 grew on $p$-hydroxybenzoate and cinnamate to the same extent as on benzoate, whereas it showed no growth on the other aromatic compounds such as protocatechuate, phenylacetate and $p$-hydroxyphenylacetate. Under aerobic conditions, the strain grew on protocatechuate, phenylacetate and $p$-hydroxyphenylacetate, but did not grow on benzoate, $p$-hydroxybenzoate or cinnamate. The other aromatic compounds such as $o$ - and $m$-hydroxybenzoates, $m$ - and $p$-methylbenzoates, $m$ - and $p$-chlorobenzoates, $p$-methoxybenzoate, phthalates, benzenesulfonate, thiophene-2-carboxylate, furan-2-carboxylate, pyridinecarboxylates and phenol were not utilized for growth under either condition. The substrates utilized in each condition were quite different.

\section{Photometabolism of aromatic compounds by the washed cells grown photosynthetically on benzoate}

Table I shows the relative rates for various aromatic compounds, determined with benzoate as a standard substrate, in the photometabolism by the washed cells grown photosynthetically on benzoate. Many kinds of aromatic compounds which were not utilized for growth were metabolized under photosynthetic conditions. Among them, thiophene-2carboxylate was metabolized most rapidly. $\alpha$ Picolinate was also metabolized more rapidly 
Table I. Relative Rates for Aromatic Compounds in the Photometabolism by the Benzoate-grown Cells

\begin{tabular}{lclc}
\hline \multicolumn{1}{c}{ Substrate } & $\begin{array}{c}\text { Relative } \\
\text { rate }^{a}\end{array}$ & \multicolumn{1}{c}{ Substrate } & $\begin{array}{c}\text { Relative } \\
\text { rate }^{a}\end{array}$ \\
\hline Thiophene-2-carboxylate & 2.74 & $m$-Hydroxybenzoate & 0.65 \\
Cinnamate & 2.11 & Furan-2-carboxylate & 0.47 \\
$\alpha$-Picolinate & 1.16 & $o$-Hydroxybenzoate & 0.31 \\
$p$-Hydroxybenzoate & 1.14 & Protocatechuate & 0.29 \\
Benzoate & $(1.00)$ & 2,4-Dihydroxybenzoate & 0.19 \\
$m$-Chlorobenzoate & 0.98 & $p$-Methylbenzoate & 0.12 \\
$m$-Methylbenzoate & 0.86 & $p$-Chlorobenzoate & 0.05 \\
\hline
\end{tabular}

a Each bottle $(500 \mathrm{ml})$ contained, in $200 \mathrm{ml}$ of $0.05 \mathrm{M}$ phosphate buffer, $\mathrm{pH} 7.0$ : a substrate, $10 \mathrm{mg}$; and cells, $c a$. $280 \mathrm{mg}$ (dry wt.). Temperature: $30^{\circ} \mathrm{C}$. Atmosphere: nitrogen. The relative rate is expressed as the relative value to the initial rate for benzoate, the standard substrate, which is taken as 1.00 .

than benzoate. $o$ - and $m$-Hydroxybenzoates were metabolized more slowly than the $p$ isomer, while the $m$-isomers were metabolized more rapidly than the corresponding $p$-isomers in the cases of chloro- and methylbenzoates. Furan-2-carboxylate was metabolized at a much slower rate than thiophene-2carboxylate. In spite of the broad substrate specificity of photometabolism, none of the following aromatic compounds were photometabolized at all: thiophene-3-carboxylate, nicotinate, isonicotinate, 1- and 2-naphthoates, phthalates, 2,3- and 3,5-dihydroxybenzoates, $p$-methoxybenzoate, phenylacetate, $p$-hydroxyphenylacetate, 3-indoleacetate, Lphenylalanine, L-tyrosine, L-tryptophane, benzenesulfonate and phenol.

\section{Photometabolism of thiophene-2-carboxylate by} the washed cells grown photosynthetically on benzoate

(a) Effects of air and darkness. Suspensions of the washed cells grown photosynthetically on benzoate were allowed to metabolize thiophene-2-carboxylate under photosynthetic conditions for $1.5 \mathrm{hr}$, after which air was admitted into one bottle in the light, while illumination was stopped for another bottle by covering it with aluminium foil under anaerobic conditions. After one hour, nitrogen gas was bubbled into the first bottle, and the cover of aluminium foil was removed from the second bottle. In this manner both bottles were

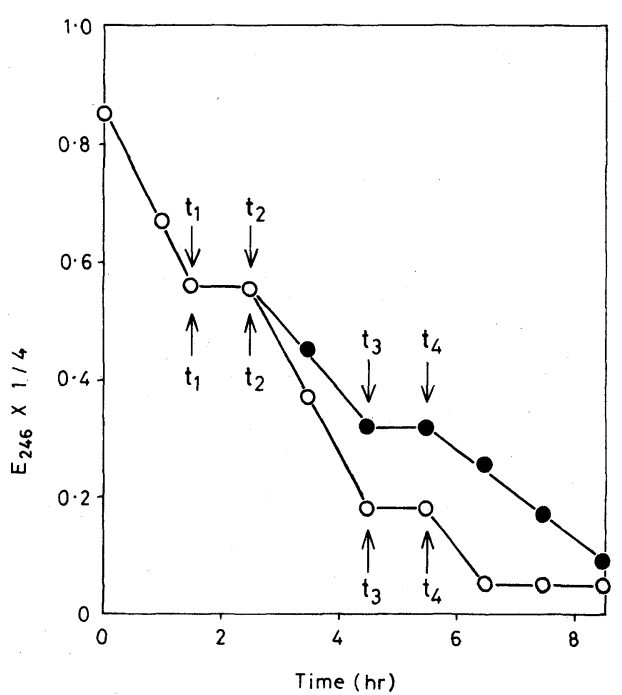

Fig. 1. Effects of Air and Darkness on the Photometabolism of Thiophene-2-carboxylate by the Benzoategrown Cells.

Each bottle $(500 \mathrm{ml})$ contained, in $200 \mathrm{ml}$ of $0.05 \mathrm{M}$ phosphate buffer, $\mathrm{pH} 7.0$ : the substrate, $.10 \mathrm{mg}$; and cells, $c a$. $300 \mathrm{mg}$ (dry wt.). Temperature: $30^{\circ} \mathrm{C}$. Atmosphere: nitrogen. In the periods between $t_{1}$ and $t_{2}$ and between $t_{3}$ and $t_{4}$, air was admitted into one bottle in the light $(\bullet)$ and illumination was stopped for another bottle under an atmosphere of nitrogen $(O)$.

returned to photosynthetic conditions. Photometabolism was again allowed to proceed for two hours, then each bottle was again put under nonphotosynthetic conditions in the same way as described above. After one hour, both bottles were again returned to photosynthetic conditions. The results (Fig. 1) show 
that admission of air or interruption of illumination caused an immediate cessation of the metabolism of thiophene-2-carboxylate and the return to photosynthetic conditions caused an instant restoration of the ability to metabolize this substrate with little loss of activity. Thus both anaerobiosis and illumination were essential for the metabolism of thiophene-2-

Table IIa. The Effects of Aliphatic

Alcohols and Carboxylates on the

Rate of the Photometabolism of

THIOPHENE-2-CARBOXYLATE BY THE BENZOATE-GROWN CELLS

\begin{tabular}{|c|c|c|c|}
\hline Additive & $\begin{array}{l}\text { Relative } \\
\text { rate }^{a}\end{array}$ & Additive & $\begin{array}{c}\text { Relative } \\
\text { rate }^{a}\end{array}$ \\
\hline Lactate & 0.55 & Glucose & 1.05 \\
\hline Succinate & 0.84 & Ethanol & 1.11 \\
\hline (None) & $(1.00)$ & Methanol & 1.22 \\
\hline
\end{tabular}

a Each bottle $(500 \mathrm{ml})$ contained, in $200 \mathrm{ml}$ of $0.05 \mathrm{M}$ phosphate buffer, $\mathrm{pH}$ 7.0: thiophene-2-carboxylate, $10 \mathrm{mg}$ ( $78 \mu \mathrm{mol})$; an additive, $400 \mu \mathrm{mol}$; and cells, $c a$. $350 \mathrm{mg}$ (dry wt.). Temperature: $30^{\circ} \mathrm{C}$. Atmosphere: nitrogen. The relative rate is expressed as the relative value to the rate in the case of no additive.
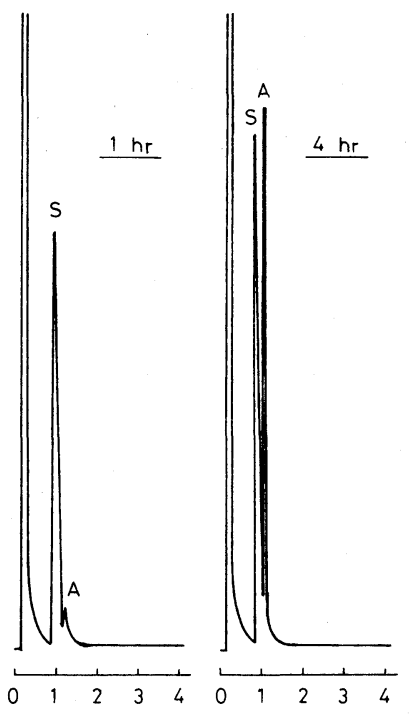

Fig. 2. GLC of the Methylated Samples of the Metabolites at Different Stages of the Photometabolism of Thiophene-2-carboxylate by the Benzoate-grown Cells.

Column: $\phi 3 \mathrm{~mm} \times 1.0 \mathrm{~m}, 2 \%$ silicone OV-1 on Chromosorb W AW-DMCS, $80 \sim 100 \mathrm{mesh}$. Carrier gas: He, $30 \mathrm{ml} / \mathrm{min}$. Temperatures: injection and detector ports, 180 and $160^{\circ} \mathrm{C}$, respectively; column, $130 \sim 160^{\circ} \mathrm{C}$ at a rate of $5^{\circ} \mathrm{C} / \mathrm{min}$.

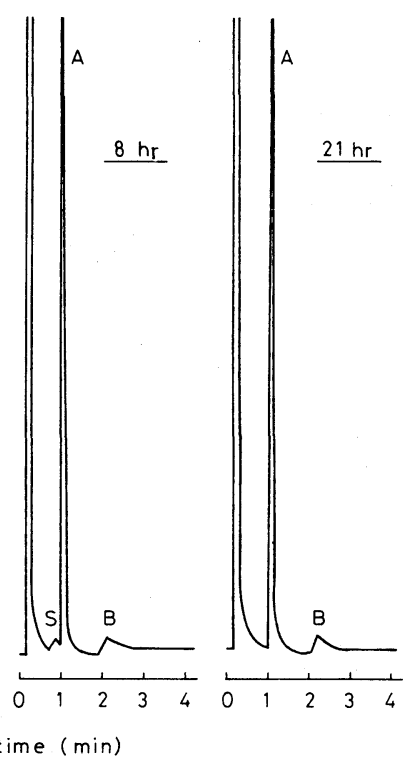

carboxylate.

(b) Effects of aliphatic alcohols and carboxylates. The photometabolism of thiophene-2carboxylate was influenced by the presence of aliphatic alcohols or carboxylates. Alcohols accelerated, while carboxylates retarded, the photometabolism of the substrate (Table IIa). Photometabolism was stimulated by methanol

Table IIb. The Effects of Aliphatic

Alcohols and Carboxylates on the

Rate of the Photometabolism of BenzoATE By THE BenzoAteGROWN CELLS

\begin{tabular}{|c|c|c|c|}
\hline Additive & $\begin{array}{c}\text { Relative } \\
\text { rate }^{a}\end{array}$ & Additive & $\begin{array}{c}\text { Relative } \\
\text { rate }^{a}\end{array}$ \\
\hline Acetate & 0.41 & Glycerol & 1.14 \\
\hline Succinate & 0.44 & Ethylene & 10 \\
\hline $\begin{array}{l}\text { Cyclohexane- } \\
\text { carboxylate }\end{array}$ & 0.60 & $\begin{array}{c}\text { glycol } \\
\text { Methanol }\end{array}$ & $\begin{array}{l}1.62 \\
2.26\end{array}$ \\
\hline Pimelate & 0.69 & Glucose & 2.34 \\
\hline $\begin{array}{l}\text { Lactate } \\
\text { (None) }\end{array}$ & $\begin{array}{c}0.70 \\
(1.00)\end{array}$ & Ethanol & 2.43 \\
\hline
\end{tabular}

a See the footnote in Table IIa. The same conditions were used as those in Table IIa, except that $50 \mathrm{mg}$ of additives was used. 
and glucose to the same extent as by ethanol. A similar phenomenon was also observed in the photometabolism of benzoate (Table IIb).

(c) Analyses of the metabolites. The photometabolism of thiophene-2-carboxylate was followed spectrophotometrically by scanning the centrifuged supernatants in the UV region of $220 \sim 300 \mathrm{~nm}\left(\lambda_{\max } 246 \mathrm{~nm}\right)$, and the methylated samples at different stages of the photometabolism were analyzed by GLC (Fig. 2). As the photometabolism progressed, the decrease of the substrate (peak S) was accompanied by an increase of metabolite A (peak A). Towards the end of the photometabolism, a trace amount of second metabolite B (peak B) appeared, but neither the decrease of metabolite A nor the increase of metabolite B occurred during further metabolism. The GLC-MS spectrum of peak A showed fragment peaks at $(\mathrm{m} / \mathrm{z}): 146\left(\mathrm{M}^{+}\right), 87\left(\mathrm{M}^{+}-\mathrm{CO}_{2} \mathrm{Me}\right.$, base peak), $59\left(87-\mathrm{C}_{2} \mathrm{H}_{4}\right)$, and $45\left(\mathrm{CHS}^{+}\right)$. Both that the mass spectral molecular weight was larger by four mass units than that of the methyl ester of thiophene-2-carboxylate, the substrate, and that the base peak had an $m / z$ value corresponding to the loss of a $\mathrm{CO}_{2} \mathrm{Me}$ group from $\mathrm{M}^{+}$suggested the formation of methyl tetrahydrothiophene-2-carboxylate. The presence of the other significant peaks $(\mathrm{m} / \mathrm{z}: 59$,
45) characteristic of a tetrahydrothiophene ring also favored the formation of the above ester. The ${ }^{1} \mathrm{H}-\mathrm{NMR}$ spectrum of metabolite $\mathrm{A}$ purified on recrystallization $\left(\delta_{\mathrm{TMS}}^{\mathrm{CDCl}_{3}}, \mathrm{ppm}\right): 2.12$ $(4 \mathrm{H}, \mathrm{m}), 2.94(2 \mathrm{H}, \mathrm{m}), 3.90(1 \mathrm{H}, \mathrm{m}), 10.82(1 \mathrm{H}$, $\mathrm{s})$. Aromatic protons disappeared and aliphatic protons appeared, but no olefinic protons were observed. From the results of both GLC-MS and ${ }^{1} \mathrm{H}-\mathrm{NMR}$ spectrometries, metabolite A was considered to be tetrahydrothiophene-2-carboxylic acid. The UV spectral data of metabolite A $\left(\lambda{ }_{\max }^{96 \% \mathrm{EtOH}} \mathrm{nm}(\varepsilon)\right.$ : 252 (220)) were similar to those reported by Claeson and Jonsson ${ }^{12)}(\lambda \underset{\max }{\mathrm{EtOH}} \mathrm{nm}(\varepsilon): 252$ (225)). Metabolite A showed a specific rotation of $[\alpha]_{D}^{27}+137.2^{\circ}(c=0.489,96 \%$ EtOH $)$, somewhat lower than the value reported by Claeson and Jonsson $\left.{ }^{12}\right)\left([\alpha]_{\mathrm{D}}^{25}+155.7^{\circ}(c=\right.$ $0.427,96 \% \mathrm{EtOH}))$. The melting point of metabolite A was $28 \sim 32^{\circ} \mathrm{C}$ (from $n$-hexane), while the reported values ${ }^{12)}$ for tetrahydrothiophene-2carboxylic acid (I) (from ligroin) are $52.0 \sim 52.5^{\circ} \mathrm{C}$ for $( \pm)-\mathrm{I}, 36 \sim 38^{\circ} \mathrm{C}$ for $(+)-\mathrm{I}$, and about $30^{\circ} \mathrm{C}$, the minimum value, for a mixture of $86 \%$ of $(+)-\mathrm{I}$ and $14 \%$ of $(-)-\mathrm{I}$, respectively. From these results, thiophene-2carboxylate was found to be reduced to its tetrahydro derivative with very high stereospecificity by the cells grown photosynthetically

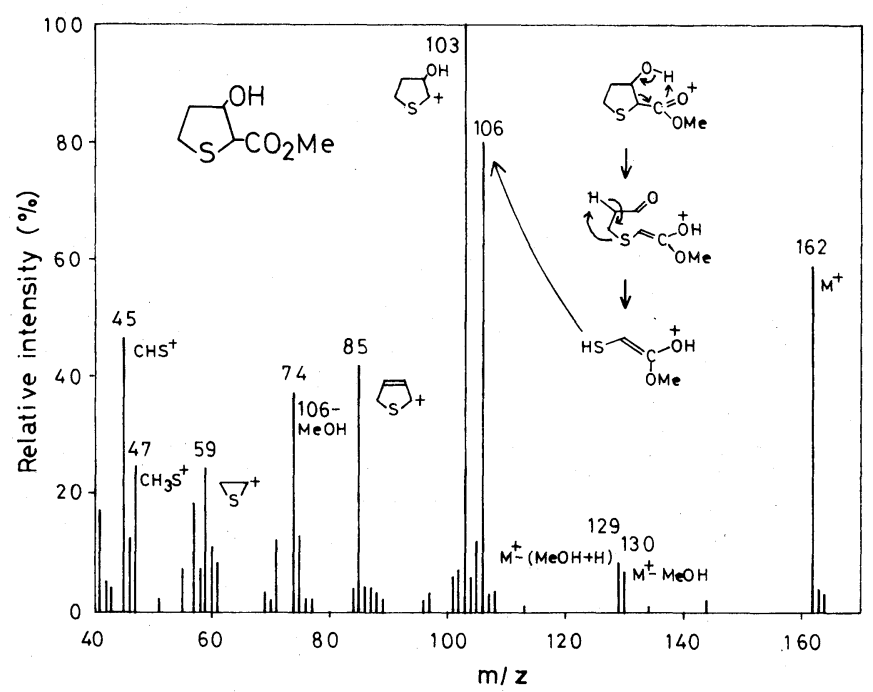

FIG. 3. Mass Spectrum of the Methylated Derivative of Metabolite B. Ionization voltage: $70 \mathrm{eV}$. Ionization current: $300 \mu \mathrm{A}$. 
on benzoate. The mass spectral molecular weight of the methylated derivative of metabolite B, 162, was larger by 16 mass units than that of metabolite A (Fig. 3). This, along with the known fact that 2-hydroxycyclohexanecarboxylate is formed as an intermediate in the photometabolism of benzoate, ${ }^{3)}$ suggested the structure of methyl 3hydroxytetrahydrothiophene-2-carboxylate for peak B. The fragmentation of its mass spectrum could be well accounted for as shown in Fig. 3. The details with regard to the structural determination of metabolite $B$ are described in the next section.

Photometabolism of thiophene-2-carboxylate by the washed cells grown photosynthetically on succinate

(a) Induction of the metabolic system. As described above, the washed cells grown photosynthetically on benzoate photometabolized thiophene-2-carboxylate about three times faster than benzoate, and no lag period was observed. On the other hand, the washed cells grown photosynthetically on succinate of the same strain began to photometabolize both benzoate and thiophene-2-carboxylate after a several hours lag period. And in this case, benzoate was metabolized more rapidly than thiophene-2-carboxylate. When chloramphenicol, an inhibitor of protein synthesis, was added $(200 \mathrm{mg} /$ liter $)$ before the photometabolism was started, the washed cells grown photosynthetically on succinate could not photometabolize either substrate at all even after $30 \mathrm{hr}$ incubation. On the contrary, the washed cells grown photosynthetically on benzoate could photometabolize both substrates at the same rates as in the case of no inhibitor, and there was no lag period in spite of the presence of such a large quantity of the inhibitor. The metabolism of thiophene-2-carboxylate by the washed cells grown photosynthetically on succinate could also occur only under photosynthetic conditions.

(b) Analyses of the metabolites. The disappearance of the substrate and the appearance of the metabolites was followed by UV spectrophotometry and GLC in the same manner as for the photometabolism by the benzoategrown cells. With regard to retention time, peaks $A^{\prime}$ and $B^{\prime}$ due to the metabolites (Fig. 4)
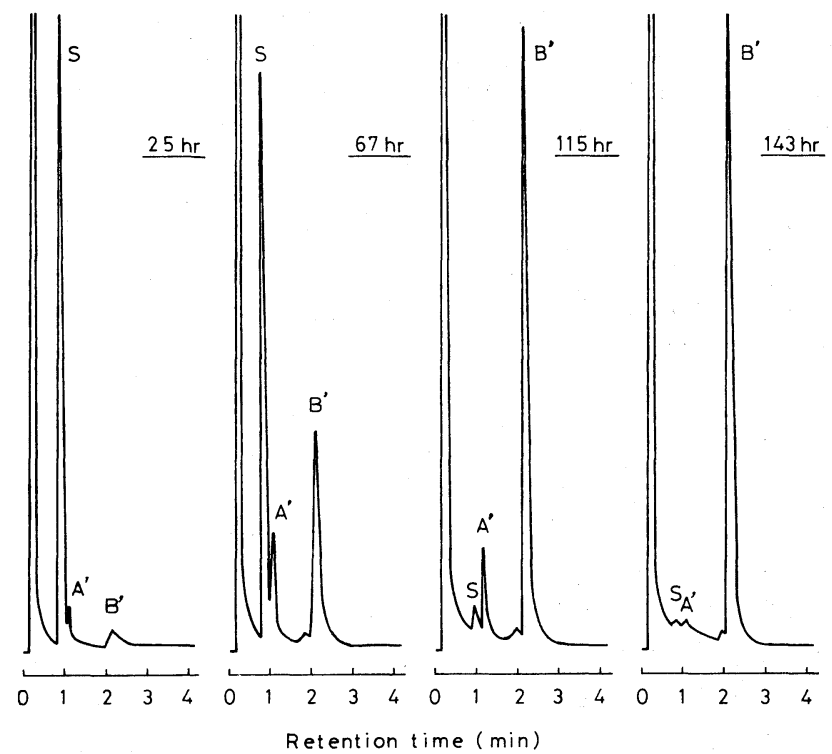

FIG. 4. GLC of the Methylated Samples of the Metabolites at Differnt Stages of the Photometabolism of Thiophene-2-carboxylate by the Succinate-grown Cells.

Analytical conditions were the same as those in Fig. 2. 


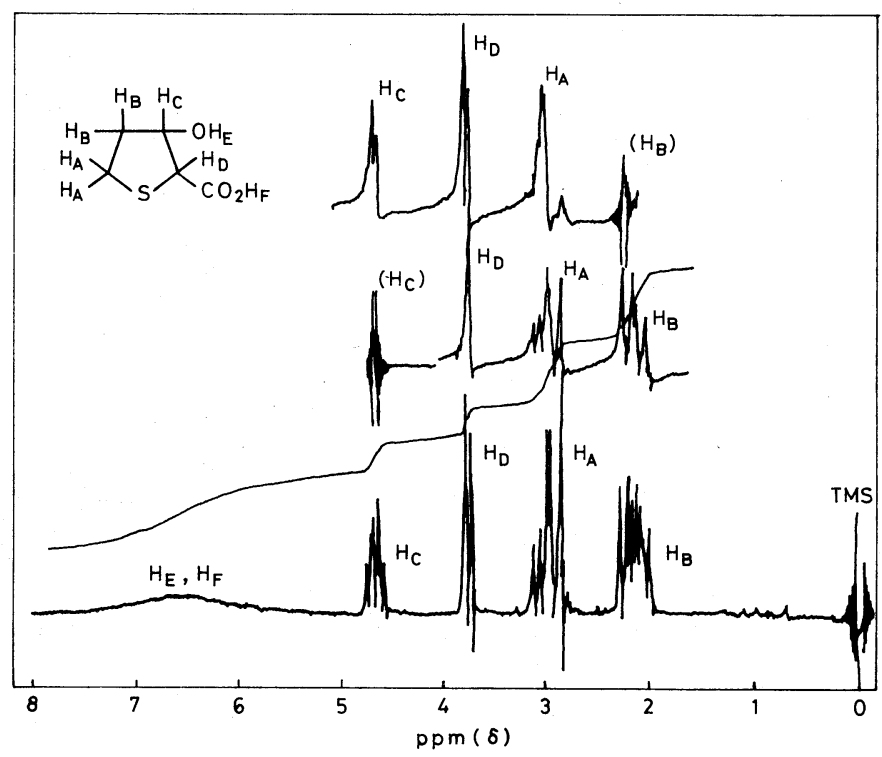

FIG. 5. ${ }^{1} \mathrm{H}-\mathrm{NMR}$ Spectrum of Metabolite $\mathrm{B}$ at $60 \mathrm{MHz}$ in $\mathrm{CD}_{3} \mathrm{COCD}_{3}$.

were identical with peaks A and B in Fig. 2, respectively. Furthermore, the GLC-MS spectra of peaks $A^{\prime}$ and $B^{\prime}$ were exactly the same as those of peaks $A$ and $B$, respectively. Thus, the same two metabolites, $\mathrm{A}$ and $\mathrm{B}$, were found to be formed by both benzoate- and succinate-grown cells, although the main metabolite was $A$ in the case of the benzoate-grown cells and $\mathrm{B}$ in the case of the succinate-grown cells, respectively. The structure of metabolite $\mathrm{B}$ was confirmed by the GLC-MS spectrum of its methylated derivative and the ${ }^{1} \mathrm{H}-\mathrm{NMR}$ spectrum of the sample purified on recrystallization (Fig. 5). Each proton was assigned as shown in Fig. 5 by the chemical shift, the coupling pattern, and the number of protons of each peak, and the proton decoupling experiments at $\mathrm{H}_{\mathrm{B}}$ and $\mathrm{H}_{\mathrm{C}}$. IR $v_{\max }^{\mathrm{KBr}} \mathrm{cm}^{-1}: 3360(\mathrm{OH}), 1720\left(\mathrm{CO}_{2} \mathrm{H}\right)$. UV $\lambda_{\max }^{96 \% \mathrm{EtOH}} \mathrm{nm}(\varepsilon): 252$ (223). Mp: $98.0 \sim 99.0^{\circ} \mathrm{C}$ ( $n$-hexane-ether). Optical rotation: $[\alpha]_{\mathrm{D}}^{27}$ $+154.2^{\circ}(c=0.251,96 \%$ EtOH $)$. Anal. Found: $\mathrm{C}, 40.38 ; \mathrm{H}, 5.50 ; \mathrm{S}, 21.82$. Calcd. for $\mathrm{C}_{5} \mathrm{H}_{8} \mathrm{O}_{3} \mathrm{~S}: \mathrm{C}, 40.53 ; \mathrm{H}, 5.44 ; \mathrm{S}, 21.64$. Thus, the succinate-grown cells converted thiophene2-carboxylate mainly into (+)-3-hydroxytetrahydrothiophene-2-carboxylate.

\section{DISCUSSION}

The strains of Rhodopseudomonas palustris that were used by Hegeman ${ }^{13)}$ and Dutton and Evans $^{3)}$ can grow on benzoate, and $p$ - and $m$ hydroxybenzoates under photosynthetic conditions, and they can grow on $p$-hydroxybenzoate and protocatechuate under aerobic conditions. On the other hand, strain H45-2 could grow on benzoate and $p$-hydroxybenzoate, but not on $m$-hydroxybenzoate under photosynthetic conditions, and it could grow on protocatechuate, but not on $p$-hydroxybenzoate under aerobic conditions. Furthermore, the rate for $p$-hydroxybenzoate is slower than those for benzoate and $m$-hydroxybenzoate in the case of the photometabolism by the cell suspension reported by Dutton and Evans, ${ }^{3)}$ while the former was faster than the latter in our case. So, our strain seems to be different from those used by the above workers with respect to both the ability to utilize aromatic compounds for growth and the relative activities for aromatic compounds in the photometabolism by cell suspensions.

Strain H45-2 could grow on very limited kinds of aromatic compounds, but a cell 
suspension of it could photometabolize not only various kinds of substituted benzoates but also a few kinds of heterocyclic aromatic compounds as shown in Table I. It seems that there is no correlation between the aromaticity and the reactivity of aromatic substrates, because the aromaticity decreases in the following order: benzoate, thiophene-2-carboxylate and furan-2-carboxylate, ${ }^{14)}$ while thiophene-2carboxylate was photometabolized most rapidly and furan-2-carboxylate most slowly in the above series of substrates.

Thiophene-3-carboxylate, nicotinate and isonicotinate, which are the ring-substituted isomers of thiophene-2-carboxylate and $\alpha$ picolinate, respectively, were not able to be photometabolized in spite of the broadness of substrate specificity in photometabolism. This rigid difference in susceptibility among the ring-substituted isomers of the heterocyclic aromatic compounds is in contrast with the fact that both $m$ - and $p$-isomers were photometabolized in the cases of methyl-, chloroand hydroxybenzoates, although there was some difference in reactivity between $m$ and $p$-isomers. Such a marked difference in susceptibility between the ring-substituted isomers has been reported in studies on both the aerobic metabolism of thiophene-2carboxylate $^{15,16)}$ and the anaerobic metabolism of nicotinate. ${ }^{17)}$

A similar difference in susceptibility among compounds with closely related structures was also observed in the following cases. 3Phenylpropionate was metabolized, but both phenylacetate and L-phenylalanine were not metabolized anaerobically by the benzoategrown cells under photosynthetic conditions. On the other hand, it has been reported that both phenylacetate and L-phenylalanine are metabolized but 3-phenylpropionate is not metabolized anaerobically by the benzoate-grown cells of a Moraxella sp. under nitrate respiration. ${ }^{5)}$ It is interesting that there is a rigid difference in susceptibility between phenylacetate and 3-phenylpropionate in both cases as above mentioned.

Photosynthetic bacteria cannot decompose water to gain reducing power as well as plants, and require inorganic or organic compounds as electron donors. In particular, rhodopseudomonads having good ability to utilize organic compounds among photosynthetic bacteria need mainly organic compounds as electron donors. Therefore, it was expected that the addition of such compounds as aliphatic alcohols and carboxylates would stimulate the reduction of aromatic substrates. Alcohols accelerated the photometabolism of thiophene-2-carboxylate and benzoate as expected, while carboxylates inhibited the reaction. Dutton and Evans ${ }^{18)}$ also reported that fatty acids strongly inhibited the photometabolism of aromatic acids by Rhodopseudomonas palustris. Therefore, it appears that aliphatic alcohols, compounds which are in a highly reduced state, stimulate the reductions of thiophene-2-carboxylate and benzoate, but that aliphatic carboxylates, compounds which are in a highly oxidized state, inhibit the reaction. However, it is not possible to explain the mechanism of the stimulating and inhibiting effects of aliphatic alcohols and carboxylates, respectively, from the results obtained in the experiments with whole cells.

The benzoate-grown cells could photometabolize not only benzoate itself but also the other aromatic compounds with various structural features with no lag period, and the addition of chloramphenicol did not affect the photometabolism of either benzoate or thiophene-2-carboxylate at all. These results indicate that various kinds of substrates would be photometabolized by an identical reduction system which is already present in the cells and of broad substrate specificity. On the contrary, the succinate-grown cells photometabolized not only benzoate but also thiophene-2carboxylate after a several hours lag period, and chloramphenicol completely inhibited the photometabolism. Therefore, it appears that the activity to photometabolize aromatic compounds is absent in the cells grown on nonaromatic compounds and the activity is induced by aromatic compounds, even if these cannot support growth. Further, the benzoate-grown 
cells gave metabolite $\mathrm{A}$, while the succinategrown cells gave metabolite $\mathrm{B}$, as the main metabolite, respectively. Thus the reduction system of the succinate-grown cells is considered to be different from that of the benzoate-grown cells.

As described above, a photosynthetic bacterium reduced a thiophene ring stereospecifically to its tetrahydro derivative. Biological reduction of such unsaturated systems as aldehydes, ketones and olefins are well known, ${ }^{19)}$ but very few studies have been done on the biological reduction of aromatic rings, especially of heterocyclic aromatic systems. The degradations of nicotinates ${ }^{17,20)}$ and pyrimidine bases ${ }^{21,22)}$ by a Clostridium sp. and the decompositions of thiophene and dibenzothiophene by anaerobic bacteria ${ }^{23)}$ have been reported for such reactions.

Thiophene rings are usually reduced to open-chain hydrocarbons with desulfurization by the catalytic reduction with Raney nickel ${ }^{24)}$ and to the dihydro derivatives by Birch reduction $^{25}$ and by electrolytic reduction, ${ }^{26)}$ respectively. The reduction with sodium amalgam can convert thiophene-2-carboxylate into its tetrahydro derivative with no desulfurization $^{27)}$ as in the photometabolism by a photosynthetic bacterium.

Therefore, the photometabolism of thiophene-2-carboxylate by a photosynthetic bacterium appears to be very characteristic in terms of anaerobic (reductive) metabolism of heterocyclic aromatic compounds and asymmetric reduction of a thiophene ring to its tetrahydro derivative with no desulfurization.

\section{REFERENCES}

1) W. C. Evans, "Fermentation Advances," ed. by D. Perlman, Academic Press Inc., New York, N. Y., 1969, pp. $649 \sim 687$.

2) S. Dagley, "Advances in Microbial Physiology," Vol. VI, ed. A. H. Rose and J. F. Wilkinson, Academic Press Inc., New York, N. Y., 1971, pp. $1 \sim 46$.
3) P. L. Dutton and W. C. Evans, Biochem. J., 113, 525 (1969).

4) M. Guyer and G. Hegeman, J. Bacteriol., 99, 906 (1969).

5) R. J. Williams and W. C. Evans, Biochem. J., 148, 1 (1975).

6) B. F. Taylor, W. L. Campbell and I. Chinoy, J. Bacteriol., 102, 430 (1970).

7) J. G. Ferry and R. S. Wolfe, Arch. Microbiol., 107, 33 (1976).

8) C. L. Keith, R. L. Bridges, L. R. Fina, K. L. Iverson and J. A. Cloran, Arch. Microbiol., 118, 173 (1978).

9) W. C. Evans, Nature, 270, 17 (1977).

10) H. D. Hartough and L. G. Conley, J. Am. Chem. Soc., 69, 3096 (1947).

11) R. Adams and A. F. Thal, "Organic Synthesis," Coll. Vol. I, John Wiley and Sons, Inc., New York, N. Y., 1941, pp. $436 \sim 438$.

12) G. Claeson and H. G. Jonsson, Ark. Kemi, 26, 247 (1966).

13) G. D. Hegeman, Arch. Microbiol., 59, 143 (1967).

14) J. D. Roberts and M. C. Caserio, "Basic Principles of Organic Chemistry," W. A. Benjamin, Inc., New York, N. Y., 1964, pp. 979 983.

15) M. J. Amphlett and A. G. Callely, Biochem. J., 112, 12p (1969).

16) R. G. Cripps, Biochem. J., 134, 353 (1973).

17) I. Harary, J. Biol. Chem., 227, 815 (1957).

18) P. L. Dutton and W. C. Evans, Arch. Biochem. Biophys., 136, 228 (1970).

19) K. Kieslich, "Microbial Transformations of Nonsteroid Cyclic Compounds," Georg Thieme Publishers, Stuttgart, 1976, pp. 629 669.

20) L. Tsai, I. Pastan and E. R. Stadtman, J. Biol. Chem., 241, 1807 (1966).

21) M. G. Hilton, G. C. Mead and S. R. Elsden, Arch. Microbiol., 102, 145 (1975).

22) R. Schäfer and A. C. Schwartz, Arch. Microbiol., 124, 111 (1980).

23) S. Kurita, T. Endo, H. Nakamura, T, Yagi and N. Tamiya, J. Gen. Appl. Microbiol., 17, 185 (1971).

24) G. M. Badger and W. H. F. Sasse, J. Chem. Soc., 1957, 3862.

25) Ya. L. Gol'dfarb, A. V. Semenovskii, E. P. Zakharov, G. V. Davydova and F. M. Stoyanovich, Izv. Akad. Nauk SSSR, Ser. Khim., 1979, 480; [C.A., 90, 168011m (1979)].

26) V. S. Mikhailov, V. P. Gul'tyai, S. G. Mairanovskii, S. Z. Taits, I. V. Proskurovskaya and Yu. G. Dubovik, Izv. Akad. Nauk SSSR, Ser. Khim., 1975, 888; [C.A., 83, 87240p (1975)].

27) F. Ernst, Chem. Ber., 20, 518 (1887). 